\title{
FAKTOR-FAKTOR YANG MEMENGARUHI MOTIVASI PARTISIPASI REMAJA PUTRI PADA TRADISI OMED-OMEDAN DI BANJAR KAJA, KELURAHAN SESETAN, DENPASAR
}

\author{
Ida Ayu Mas Ganggadewi Dwijayanthi dan David Hizkia Tobing \\ Program Studi Psikologi, Fakultas Kedokteran, Universitas Udayana \\ dayu_ganggadewi@gmail.com
}

\begin{abstract}
Abstrak
Kecenderungan yang ditemui akhir-akhir ini adalah remaja kurang berpartisipasi dalam kegiatan pelestarian budaya dan tradisi. Padahal, peran remaja dalam melestarikan budaya dan tradisi sangat penting, khususnya pada tradisi Omedomedan yang hanya diikuti oleh remaja di Banjar Kaja, Kelurahan Sesetan, Denpasar. Di sisi lain, masyarakat umum memiliki persepsi keliru terhadap tradisi Omed-omedan. Perilaku berciuman yang beberapa kali terjadi pada tradisi Omed-omedan menimbulkan stereotipe yang lebih merugikan pihak perempuan yang pada umumnya menjadi objek dari aktivitas seksual, seperti aktivitas berciuman. Perubahan jaman juga mengakibatkan tidak ada sanksi sosial yang mengikat remaja di Banjar Kaja, Kelurahan Sesetan, Denpasar untuk berpartisipasi dalam tradisi Omed-omedan.

Penelitian ini bertujuan untuk mengetahui faktor-faktor yang memengaruhi motivasi partisipasi remaja putri pada tradisi Omed-omedan di Banjar Kaja, Kelurahan Sesetan, Denpasar. Penelitian ini menggunakan metode penelitian kualitatif dengan pendekatan fenomenologi dan teknik pengumpulan data melalui wawancara mendalam dan observasi pada 6 orang remaja putri di Banjar Kaja, Kelurahan Sesetan, Denpasar. Data dianalisis dengan theoretical coding yang terdiri dari open, axial, dan selective coding. Hasil penelitian ini menunjukkan bahwa motivasi partisipasi remaja putri di Banjar Kaja, Kelurahan Sesetan dibagi menjadi dua, yaitu (1) motivasi intrinsik yang terdiri dari rasa ingin tahu, kesenangan, belief, prinsip, rasa bangga, dan informasi baru; dan (2) motivasi ekstrinsik yang terdiri dari fasilitias, kewajiban, ajakan, peran pasangan, keuntungan, mengisi waktu luang, dan tekanan sosial. Selain itu, diperoleh faktorfaktor yang menghambat partisipasi, baik yang bersifat (1) internal seperti keinginan, persepsi, rasa lelah dan (2) eksternal seperti sikap pasangan, ketersediaan waktu, ketersediaan fasilitas, tidak ada yang mengajak, tidak mengenal anggota STT lain, dan cuntaka.
\end{abstract}

Kata kunci: Motivasi, Partisipasi, Remaja putri, Omed-omedan

\begin{abstract}
Nowadays, adolescents have less participation to preserve cultural and traditional activities. In fact, the role of adolescents in preserving culture and tradition is very important, especially in Omed-omedan tradition which is only followed by adolescents in Banjar Kaja, Kelurahan Sesetan, Denpasar. On the other hand, people have a misperception about Omed-omedan tradition. Kissing behavior that occurred several times in Omed-omedan tradition causes stereotypes that are more detrimental to the women who generally become object of sexual activity, such as kissing. Changing times also affect to the absence of social sanction on Omed-omedan tradition.

This research aims to find out factors that influence female adolescent's motivation to participate in Omed-omedan in Banjar Kaja, Kelurahan Sesetan, Denpasar. This is phenomenological qualitative research. Data collected by in-depth interview and observation among six female adolescents in Banjar Kaja, Kelurahan Sesetan, Denpasar. The data were analyzed with theoretical coding which consist of open, axial, and selective coding. Result show that female adolescents in Banjar Kaja, Kelurahan Sesetan, Denpasar have (1) intrinsic motivation such as curiousity, enjoyment, belief, principle, pride, and new information; and (2) extrinsic motivation such as facilities, obligation, invited, role of partner, benefit, free time, and social pressure.. In addition, there are (1) internal obstruction such as desire, perception, exhaustedness and (2) external obstruction such gesture of partner, time availability, facilities availability, absence of invitation, do not know other members in organization in bajar, and cuntaka.
\end{abstract}

Key words: Motivation, Partisipation, Female adolescent, Omed-omedan 


\section{LATAR BELAKANG}

Bali merupakan salah satu daerah tujuan pariwisata yang paling diminati wisatawan lokal maupun mancanegara. Kelestarian budaya, tradisi, keindahan alam, dan ciri khas lainnya menjadi daya tarik Pulau Bali. Roucek \& Warren (1984) mendefinisikan budaya sebagai cara hidup yang berkembang dan dimiliki oleh sebuah kelompok sedangkan Van Peursen (1988) mendefinisikan tradisi sebagai proses pewarisan atau penerusan norma-norma, adat istiadat, kaidahkaidah, dan harta-harta. Budaya dan tradisi sama-sama memerlukan sosialisasi baik secara lisan atau tertulis untuk tetap melestarikannya. Salah satu tradisi unik yang ada di Bali adalah tradisi Omed-omedan yang berasal dari bahasa Bali yang artinya tarik-menarik. Tradisi ini dilaksanakan oleh remaja di Banjar Kaja, Kelurahan Sesetan, Denpasar setiap satu tahun sekali, tepatnya satu hari setelah hari raya Nyepi.

Sebuah tradisi tidak dapat terlaksana tanpa adanya partisipasi masyarakat. Menurut Ach. Wazir Ws., et al. (1999) partisipasi dapat diartikan sebagai keterlibatan seseorang secara sadar ke dalam interaksi sosial dalam situasi tertentu. Partisipasi tidak lahir begitu saja, namun didorong oleh motivasi-motivasi tertentu. Uno (2010) menjelaskan bahwa motivasi berasal dari kata motif yang dapat diartikan sebagai kekuatan yang terdapat dalam diri individu, yang menyebabkan individu tersebut bertindak atau berbuat. Menurut Harter (dalam Lepper, Iyengar, \& Corpus, 2005), motivasi terdiri dari dua kutub berlawanan, yaitu faktor instrinsik dan ekstrinsik. Faktor intrinsik berarti motivasi berasal dari dalam diri tanpa ada paksaan maupun dorongan orang lain, sedangkan faktor ekstrinsik berarti motivasi muncul akibat stimulus yang berasal dari luar individu.

Kebudayaan Indonesia sudah mulai luntur terutama perhatian pemuda terhadap budaya nasional dimana pemuda lebih condong senang meniru budaya-budaya luar daripada budaya asli sendiri (Kompasiana, 2015). Padahal, Indonesia, khususnya masyarakat Bali, memiliki banyak budaya dan tradisi. Salah satunya adalah tradisi Omed-omedan yang melibatkan peran serta remaja sebagai anggota Sekaa Teruna Teruni (STT) yang ada di Banjar Kaja, Kelurahan Sesetan, Denpasar. Tentu diperlukan kesadaran dan partisipasi dari remaja itu sendiri.

Tradisi Omed-omedan pada dasarnya merupakan tradisi berupa dorong-mendorong dan tarik-menarik. Perubahan makna tradisi Omed-omedan menjadi bergeser, khususnya di masyarakat, yang kemudian menganggap bahwa tradisi Omed-omedan merupakan tradisi ciuman massal. Sekitar tahun 1984-an, tokoh masyarakat di Banjar Kaja, Kelurahan Sesetan, Denpasar merencanakan meniadakan tradisi Omed-omedan dengan alasan adanya cemoohan bahwa remaja di Banjar Kaja, Kelurahan Sesetan, Denpasar mengadakan hiburan dengan variasi cium-ciuman di depan umum (Munggah, 2008).
Penelitian yang dilakukan oleh Cahyadinata (2013) menunjukan bahwa: (1) latar belakang sejarah munculnya tradisi Omed-omedan di Banjar Kaja, Kelurahan Sesetan, Denpasar, adalah berawal dari Anak Agung Made Raka yang mengatur pemerintahan di Desa Sesetan sedang menderinta sakit keras yang tidak kunjung sembuh. Anak Agung Made Raka sembuh setelah melihat warga saling tarik dan dorong yang kemudian diperintahkan untuk dilaksanakan sepanjang tahun pada hari Nyepi; (2) aspek sosio-budaya dan religius tradisi Omed-omedan yaitu dari aspek sosial berupa terciptanya rasa kekeluargaan, mempererat hubungan antar masyarakat, dan memupuk rasa kesetiakawanan diantara masyarakat Banjar Kaja. Aspek budaya adalah masyarakat Banjar Kaja, Kelurahan Sesetan, Denpasar ikut berperan penting dalam melestarikan dan mempertahankan tradisi Omed-omedan. Aspek religi adalah sarana peningkatan spiritual melalui pementasan sakral tradisi Omed-omedan; (3) strategi pemertahanan tradisi Omed-omedan di Banjar Kaja, adalah dengan cara memberikan pengarahan berupa sosialisasi dan pengawasan kepada remaja Banjar Kaja, Sesetan, tentang betapa pentingnya menjaga dan melestarikan tradisi yang telah diwariskan.

Pemberitaan media mengenai image keliru tentang tradisi Omed-omedan terus terjadi. Peneliti menemukan adanya beberapa artikel di internet yang menyatakan bahwa Omed-omedan merupakan tradisi ciuman massal ala anak muda Bali. Salah satu artikel yang ditulis oleh Widodo (2016) menyatakan bahwa ratusan remaja Bali saling berciuman pada tradisi Omed-omedan. Pernyataan dan judul dalam artikel tersebut dapat menimbulkan persepsi yang keliru dalam masyarakat, tidak hanya masyarakat Bali namun juga masyarakat dunia.

Dilihat dari sudut pandang budaya, Omed-omedan tidak lebih dari sebuah ritual sakral yang dilakukan secara turun temurun, namun apabila dilihat dari sisi pornografi, adegan ciuman dalam omed-omedan tidak pantas dilakukan (Paduarsana, 2012). Artikel tersebut dapat menimbulkan skema baru tentang remaja khususnya di Banjar Kaja, Kelurahan Sesetan, Denpasar terkait pelaksanaan tradisi Omed-omedan. Skema baru yang muncul adalah remaja putri di Banjar Kaja, Kelurahan Sesetan, Denpasar mau melakukan adegan berciuman di depan umum, bahkan dengan laki-laki yang bukan pacar remaja putri tersebut, sedangkan skema yang sudah terbentuk dalam masyarakat adalah remaja putri tidak berciuman di depan umum walaupun dengan pacar remaja putri tersebut. Skema yang bertentangan tersebut dapat menimbulkan stereotipe yang cenderung negatif pada remaja putri di Banjar Kaja, Kelurahan Sesetan, Denpasar. Stereotipe adalah keyakinan tentang karakteristik khas dari anggota suatu kelompok atau kategori sosial (Taylor, dkk., 2009).

Munculnya stereotipe yang negatif tersebut diakibatkan karena stereotipe biasanya menekankan pada 
atribut tertentu, khususnya atribut yang tidak disukai dan cenderung mengabaikan variasi dalam suatu kelompok (Taylor, dkk., 2009). Artinya, munculnya stereotipe yang negatif dalam tradisi Omed-omedan diakibatkan adanya penekanan pada aktivitas ciuman yang dilakukan pada orang yang bukan pacarnya, sehingga memberikan kesan bahwa tradisi ini mengandung pornografi dan stereotipe itu pun mulai terbentuk di masyarakat.

Budaya patriarki menempatkan posisi sosial kaum laki-laki lebih tinggi daripada kaum perempuan (Erdianto, 2017). Kajian budaya telah mempelajari representasi perempuan dalam budaya populer dan dalam sastra, dan mendapatkan bahwa perempuan di seluruh dunia terkonstitusi sebagai kelamin dan tersubordinasi di bawah lelaki (Juditha, 2015). Hal ini menjadikan perempuan sebagai individu yang harus menuruti laki-laki, hingga akhirnya menjadi objek dari aktivitas yang dilakukan oleh laki-laki. Salah satunya adalah menjadi objek dalam aktivitas seksual seperti berciuman.

Aktivitas berciuman yang sempat terjadi pada tradisi Omed-omedan memberikan kesan negatif bahwa remaja putri di Banjar Kaja, Kelurahan Sesetan, Denpasar menjadi objek dari aktivitas yang belum tentu diinginkan oleh kedua belah pihak. Hal ini dapat menjadi salah satu faktor yang memengaruhi pengambilan keputusan untuk berpartisipasi pada tradisi Omed-omedan, khususnya bagi remaja putri di Banjar Kaja, Kelurahan Sesetan, Denpasar.

Hasil wawancara dengan Ketua STT yang ada di Banjar Kaja, Kelurahan Sesetan, Denpasar, dinyatakan bahwa sekitar tahun 1970 atau 1980-an, pemuda atau pemudi yang tidak mengikuti Omed-omedan akan dicari ke rumah dan dilempari tanah liat atau lumpur sehingga mau tidak mau orang tersebut harus ke banjar (Dwijayanthi, 2016). Hal tersebut termasuk dalam bentuk sanksi sosial. Saat ini, sanksi tersebut sudah tidak berlaku karena masyarakat memiliki kesibukan masing-masing.

Pemaparan diatas menyimpulkan bahwa saat ini remaja di Indonesia kurang berpartisipasi dalam kegiatan pelestarian budaya dan tradisi. Di sisi lain, masyarakat memiliki persepsi keliru terhadap tradisi Omed-omedan yang salah satunya disebabkan oleh informasi dari media elektronik. Posisi perempuan dalam budaya patriarki menyebabkan perempuan cenderung menjadi objek dari aktivitas yang belum tentu diinginkan kedua belah pihak, salah satunya adalah aktivitas berciuman yang pernah beberapa kali terjadi pada tradisi Omed-omedan. Perubahan jaman juga mengakibatkan perubahan pada sanksi sosial, dimana saat ini sudah tidak ada sanksi sosial yang mengikat remaja di Banjar Kaja, Kelurahan Sesetan, Denpasar untuk berpartisipasi pada tradisi Omed-omedan. Hal-hal tersebut dapat memengaruhi motivasi partisipasi remaja putri pada tradisi Omed-omedan di Banjar Kaja, Kelurahan Sesetan, Denpasar.
Berdasarkan pemaparan diatas, dapat disimpulkan bahwa penelitian ini berfokus pada penggalian data terkait faktor-faktor yang memengaruhi motivasi partisipasi remaja putri pada tradisi Omed-omedan di Banjar Kaja, Kelurahan Sesetan, Denpasar.

\section{METODE PENELITIAN}

Penelitian ini menggunakan metode penelitian kualitatif, karena metode penelitian kualitatif dapat melihat fenomena secara luas dan mendalam sesuai pada situasi sosial yang terjadi. Penelitian kualitatif adalah penelitian yang bermaksud untuk memahami fenomena tentang apa yang dialami oleh subjek penelitian misalnya perilaku, persepsi, dan motivasi (Moleong, 2014). Penelitian ini menggunakan pendekatan fenomenologi, karena pendekatan fenomenologi merupakan pandangan berpikir yang menekankan pada fokus kepada pengalaman-pengalaman subjektif manusia dan interpretasi-interpretasi dunia (Moleong, 2014).

\section{Karakteristik Responden}

Penelitian ini menggunakan enam orang responden yang merupakan anggota STT di Banjar Kaja, Kelurahan Sesetan, Denpasar. Responden rata-rata berusia 19-21 tahun dan berjenis kelamin perempuan. Peneliti mendapatkan responden melalui teknik purposive dan snowball sampling sehingga peneliti memperoleh responden susuai dengan kriteria yang ditentukan dan mendapat jumlah responden berdasarkan konsep kejenuhan data, dimana data yang didapatkan dari responden penelitian yang satu telah dibandingkan dengan responden penelitian lainnya dan menemukan kejenuhan informasi.

Adapun karakteristik responden penelitian dapat dilihat sebagai berikut:

\begin{tabular}{ll} 
& Tabel 1. Karakteristik Responden \\
\hline Kode Responden & Karakteristik Responden \\
\hline Responden DA & Usia : 21 tahun \\
& Pekerjaan : Mahasiswa \\
& Frekuensi Partisipasi : 1x \\
\hline Responden NS & Usia : 21 tahun \\
& Pekerjaan : Mahasiswa \\
& Frekuensi Partisipasi : $4 \mathrm{x}$ \\
\hline Responden DN & Usia : 21 tahun \\
& Pekerjaan : Mahasiswa \\
& Frekuensi Partisipasi : $4 \mathrm{x}$ \\
\hline Responden NI & Usia : 19 tahun \\
& Pekerjaan : Mahasiswa \\
& Frekuensi Partisipasi : $3 \mathrm{x}$ \\
\hline Responden PT & Usia : 19 tahun \\
& Pekerjaan : Mahasiswa \\
& Frekuensi Partisipasi : $3 \mathrm{x}$ \\
\hline Responden YA & Usia : 21 tahun \\
& Pekerjaan : Mahasiswa \\
& Frekuensi Partisipasi : 1x \\
\hline
\end{tabular}




\section{Lokasi Pengumpulan Data}

Lokasi pengumpulan data dalam penelitian ini dilakukan diseputaran wilayah Kota Denpasar, khususnya wilayah Denpasar Selatan. Lokasi pengumpulan data ditentukan dengan mempertimbangkan tempat tinggal keenam responden yaitu di Banjar Kaja, Kelurahan Sesetan, Denpasar sehingga responden tidak keberatan melakukan wawancara diluar rumah karena lokasi yang disepakati tidak terlalu jauh dari rumah responden.

\section{Teknik Pengumpulan Data}

Teknik pengambilan data menggunakan wawancara semi terstruktur. Tujuan dari wawancara jenis ini adalah untuk menemukan permasalahan secara lebih terbuka, dimana pihak yang diwawancarai diminta pendapat dan ide-idenya (Sugiyono, 2013). Peneliti melakukan wawancara dengan panduan guideline yang sebelumnya telah dibuat peneliti dalam poin-poin besar, sehingga peneliti tidak terlalu berpatokan dengan guideline. Peneliti juga memperdalam jawaban responden melalui probing. Berikut adalah tabel waktu pengambilan data dengan wawancara yang telah dilakukan dalam penelitian ini:

\begin{tabular}{|c|c|c|c|}
\hline Responden & Kegiatan & Hari, Tanggal & Tempat \\
\hline Responden & - Membangun rapport \& memberikan & - Senin, 26-12-16 & - Br. Kaja \\
\hline \multirow[t]{4}{*}{$\mathrm{DA}$} & informed consent & & \\
\hline & - Wawancara I & - Kamis, 29-12-16 & - Dunkin Donuts \\
\hline & - Member check dan pemberian & -Sabtu, 31-01-17 & - Br. Kaja \\
\hline & kenang-kenangan & & \\
\hline \multirow[t]{5}{*}{ Responden NS } & - Membangun rapport \& memberikan & -Subtu, 22-10-16 & - Br. Kaja \\
\hline & informed consent & & \\
\hline & - Wawancara I & -Senin, 24-10-16 & -Sambal Nyornyor \\
\hline & - Member check dan pemberian & - Kamis, 30-03-17 & - Br. Kaja \\
\hline & kenang-kenangan & & \\
\hline \multirow{4}{*}{$\begin{array}{l}\text { Responden } \\
\text { DN }\end{array}$} & - Membangun rapport \& memberikan & - Kamis, 19-01-17 & - Br. Kaja \\
\hline & informed consent & & \\
\hline & - Wawancara I & - Senin, 23-01-17 & - Br. Kaja \\
\hline & $\begin{array}{l}\text { - Wawancara II, member check dan } \\
\text { pemberian kenang-kenangan }\end{array}$ & - Minggu, 26-03-17 & - Buddy's Gelato \\
\hline \multirow[t]{4}{*}{ Responden NI } & - Membangun rapport \& memberikan & - Kamis, 19-01-17 & - Br. Kaja \\
\hline & - Wawancara I & -Senin, 23-01-17 & - Br. Kaja \\
\hline & - Member check dan pemberian & - Kamis, 30-03-17 & - Br. Kaja \\
\hline & kenang-kenangan & & \\
\hline \multirow[t]{5}{*}{ Responden PT } & - Membangun rapport \& memberikan & -Minggu, 05-02-17 & - Br. Kaja \\
\hline & informed consent & & \\
\hline & - Wawancara I & - Rabu, 08-02-17 & - Buddy's Gelato \\
\hline & - Member check dan pemberian & - Jumat, 31-03-17 & - Br. Kaja \\
\hline & kenang-kenangan & & \\
\hline Responden & - Membangun rapport \& memberikan & - Minggu, 05-02-17 & - Br. Kaja \\
\hline \multirow[t]{4}{*}{ YA } & informed consent & & \\
\hline & - Wawancara I & -Kamis, 09-2-17 & -Sambal Nyomyor \\
\hline & - Member check dan pemberian & - Sabtu, 31-03-17 & - Br. Kaja \\
\hline & kenang-kenangan & & \\
\hline
\end{tabular}

Selain itu, peneliti menggunakan teknik observasi (participant observation). Selama proses pelaksanaan wawancara dan observasi, peneliti juga melakukan pencatatan informasi penting agar tidak terlupakan atau terabaikan oleh peneliti yang kemudian disempurnakan ke dalam bentuk catatan lapangan (fieldnote). Berikut adalah tabel waktu pengambilan data dengan observasi yang telah dilakukan dalam penelitian ini:

Tabel 3. Pelaksanaan Observasi

\begin{tabular}{|c|c|c|}
\hline Responden & $\begin{array}{c}\text { Waktu } \\
\text { Pelaksanaan }\end{array}$ & Lokasi \\
\hline \multirow[t]{2}{*}{ Responden DA } & - Kamis, 29-12-16 & - Dunkin Donuts, J. P. B. Sudirman, Denpasar \\
\hline & - Rabu, 29-03-17 & - Br. Kaja, Kelurahan Sesetan, Denpasar, Denpasar \\
\hline \multirow[t]{2}{*}{ Responden NS } & - Senin, 24-10-16 & - Sambal Nyornyor, J. P.B. Sudirman, Denpasar \\
\hline & - Rabu, 29-03-17 & - Br. Kaja, Kelurahan Sesetan, Denpasar, Denpasar \\
\hline \multirow[t]{3}{*}{ Responden DN } & - Senin, 23-01-17 & $\begin{array}{l}\text { - Balai Br. Kaja, Kelurahan Sesetan, Denpasar, } \\
\text { Denpasar }\end{array}$ \\
\hline & - Minggu, 26-03-17 & - Buddy's Gelato, Jl. P.B. Sudirman, Denpasar \\
\hline & - Rabu, 29-03-17 & - Br. Kaja, Kelurahan Sesetan, Derpasar, Denpasar \\
\hline \multirow[t]{2}{*}{ Responden NI } & - Senin, 23-01-17 & - Balai Br. Kaja, Kelurahan Sesetan, Denpasar \\
\hline & - Rabu, 29-03-17 & - Br. Kaja, Kelurahan Sesetan, Denpasar, Denpasar \\
\hline \multirow[t]{2}{*}{ Responden PT } & - Rabu, 08-02-17 & - Buddy's Gelato, J. P. B. Sudirman, Denpasar \\
\hline & - Rabu, 29-03-17 & $\begin{array}{l}\text { - Balai Br. Kaja, Kelurahan Sesetan, Denpasar, } \\
\text { Denpasar }\end{array}$ \\
\hline \multirow[t]{2}{*}{ Responden YA } & - Kamis, 09-02-17 & - Sambal Nyornyor, J. P.B. Sudirman, Denpasar \\
\hline & - Rabu, 29-03-17 & $\begin{array}{l}\text { - Balai Br. Kaja, Kelurahan Sesetan, Denpasar, } \\
\text { Denpasar }\end{array}$ \\
\hline
\end{tabular}

\section{Teknik Analisa Data}

Bogdan dan Taylor (dalam Moleong, 2014) mendefiniskan analisis data sebagai proses yang merinci usaha secara formal untuk menemukan tema dan merumuskan hipotesis kerja (ide) seperti yang disarankan oleh data dan sebagai usaha untuk memberikan bantuan pada tema dan hipotesis kerja itu. Analisis data menggunakan teknik theoretical coding yang terdiri dari: open coding yaitu proses pembentukan kategori-kategori awal kemudian diturunkan menjadi sejumlah subkategori, axial coding yaitu mereduksi kategori-kategori pada open coding dan menghubungkan subkategori-subkategori hingga menghasilkan kategori utama, selective coding yaitu memilih dan memusatkan perhatian pada kategori yang paling signifikan serta mengaitkannya dengan kategori-kategori lain dan memvalidasi kaitan tersebut (Strauss \& Corbin, 1990).

\section{Kredibilitas Penelitian}

Pemantapan kredibilitas dalam penelitian kualitatif dapat dilakukan dengan berbagai cara. Dalam penelitian ini, teknik yang digunakan adalah teknik yang dipaparkan oleh Sugiyono (2014) yaitu:

\section{a. Perpanjangan Pengamatan}

Perpanjangan pengamatan berarti peneliti kembali ke lapangan, melakukan pengamatan, wawancara lagi dengan sumber data yang pernah ditemui saat preliminary study maupun yang baru. Melalui tahap ini, hubungan peneliti dan responden akan semakin terbentuk rapport, semakin akrab, saling mempercayai sehingga tidak ada informasi yang disembunyikan lagi.

b. Peningkatan Ketekunan 
Meningkatkan ketekunan berarti melakukan pengamatan secara lebih cermat dan berkesinambungan. Peneliti melakukan pemeriksaan kembali mengenai data yang telah ditemukan. Dengan cara tersebut maka kepastian data dan urutan peristiwa akan dapat direkam secara pasti dan sistematis.

\section{c. Triangulasi}

Triangulasi dalam pengujian kredibilitas ini diartikan sebagai pengecekan data dari berbagai sumber dengan berbagai cara, dan berbagai waktu. Peneliti akan melakukan triangulasi sumber dengan cara mengumpulkan data dari responden serta mengecek data dengan sumber yang sama dengan teknik yang berbeda yaitu menggunakan metode wawancara semi terstruktur dan teknik pengamatan.

\section{d. Analisis Kasus Negatif}

Peneliti mencari data yang berbeda atau bahkan bertentangan dengan data yang telah ditemukan. Bila tidak ada lagi data yang berbeda atau bertentangan dengan data yang ditemukan, berarti data tersebut sudah dapat dipercaya.

\section{e. Menggunakan Bahan Referensi}

Bahan referensi yang dimaksud adalah adanya pendukung untuk membuktikan data yang telah ditemukan oleh peneliti.

\section{f. Mengadakan Member check (Pengecekan Kepada Pemberi Data)}

Member check adalah proses pengecekan data yang diperoleh peneliti kepada pemberi data. Tujuan member check adalah untuk mengetahui seberapa jauh data yang diperoleh sesuai dengan apa yang diberikan oleh pemberi data. Member check dalam penelitian ini akan dilakukan setelah mendapatkan data dan setelah dilakukannya proses koding data.

\section{Isu Etika Penelitian}

Setiap penelitian memiliki isu-isu etis yang perlu diperhatikan. Isu etika dalam penelitian ini menggunakan pedoman dari kode etik psikologi Indonesia pada pasal 49 tentang informed consent dalam penelitian. Penggunaan isu etika penelitian berfungsi sebagai perlindungan bagi partisipan. Pasal 49 menyebutkan bahwa sebelum pengambilan data penelitian Psikolog dan/atau Ilmuwan Psikologi menjelaskan kepada calon partisipan penelitian dengan menggunakan bahasa yang sederhana dan istilahistilah yang dipahami masyarakat umum tentang penelitian yang akan dilakukan. Psikolog dan/atau Ilmuwan Psikologi menjelaskan kepada calon partisipan penelitian yang menyatakan bahwa keikutsertaan dalam penelitian yang dilakukan bersifat sukarela, sehingga memungkinkan pengunduran diri atau penolakan untuk terlibat. Partisipan harus menyatakan kesediaannya seperti yang dijelaskan pada pasal yang mengatur tentang itu (Himpsi, 2010).

\section{HASIL PENELITIAN}

Hasil penelitian ini akan dipaparkan berdasarkan tiga tema, yakni motivasi intrinsik, motivasi ekstrinsik dan faktor penghambat motivasi partisipasi remaha putri pada tradisi Omed-omedan di Banjar Kaja, Kelurahan Sesetan, Denpasar.

\section{Tema 1: Motivasi intrinsic}

Berdasarkan hasil analisis wawancara dan observasi, peneliti menemukan enam aspek motivasi intrinsik yaitu rasa ingin tahu atau curiousity, kesenangan, belief, prinsip, rasa bangga atau pride, dan informasi baru. Peneliti akan memaparkan keenam aspek, namun peneliti hanya membahas lima aspek sebagai temuan utama karena aspek pendukung kurang urgent untuk dibahas sebagai temuan dalam penelitian ini.

\section{a. Rasa Ingin Tahu atau Curiousity}

Dua dari enam responden menyatakan bahwa responden merasa penasaran dengan tradisi Omedomedan. Rasa penasaran yang dinyatakan responden kemudian peneliti terjemahkan dengan istilah lain, yaitu rasa ingin tahu atau curiousity yang kemudian mendorong responden untuk berpartisipasi pada tradisi Omed-omedan.

\section{b. Kesenangan}

Dua dari enam responden menyatakan bahwa responden mengikuti tradisi Omed-omedan sebagai ajang untuk bersenang-senang. Rasa senang yang dirasakan responden setelah berpartisipasi pada tradisi Omed-omedan dapat mendorong responden untuk berpartisipasi kembali pada pelaksanaan tradisi Omedomedan selanjutnya.

\section{c. Kepercayaan atau Belief}

Responden menyebutkan bahwa responden percaya pada sesuhunan di Banjar Kaja, Kelurahan Sesetan, Denpasar dan percaya bahwa tradisi Omed-omedan merupakan tradisi yang harus dilaksanakan secara rutin setiap tahunnya. Kepercayaan atau belief responden tidak memengaruhi keputusan responden untuk mengikuti tradisi Omed-omedan walaupun saat itu responden sedang berpacaran dengan laki-laki yang bukan berasal dari Banjar Kaja, Kelurahan Sesetan, Denpasar.

\section{d. Prinsip}


Sebagai generasi muda di Banjar Kaja, Kelurahan Sesetan, Denpasar, responden PT juga memiliki prinsip bahwa responden akan berpartisipasi dalam tradisi Omed-omedan selama responden masih memiliki kesempatan tersebut. Responden PT juga mengatakan bahwa responden telah mengikuti tradisi Omedomedan sejak pertama kali bergabung menjadi anggota STT dan belum pernah absen dalam tradisi Omedomedan.

\section{e. Rasa Bangga atau Pride}

responden menyatakan bahwa responden merasa bangga dengan mengikuti tradisi Omed-omedan. Responden merasa bangga karena tradisi Omedomedan merupakan tradisi yang hanya dilaksanakan satu tahun sekali, satu-satunya di Bali, bahkan dunia, dan karena tradisi ini telah mendunia.

\section{f. Informasi Baru}

Dua dari enam responden memiliki motivasi partisipasi karena telah memiliki pengetahuan tentang tradisi Omed-omedan. Responden PT mempelajari tradisi Omed-omedan dari tetua-tetua di banjar yang hadir saat anggota beserta pengurus STT mengadakan rapat. Berbeda dengan responden YA yang mendapatkan penjelasan dari pacar responden yang menjadi salah satu pengurus STT. Responden YA sempat merasa malu mengikuti tradisi Omed-omedan karena responden memiliki persepsi bahwa tradisi Omed-omedan merupakan tradisi ciuman massal. Setelah mendapatkan informasi baru tersebut, persepsi responden YA mengenai tradisi Omed-omedan menjadi berubah dan responden bersedia untuk berpartisipasi dalam tradisi Omed-omedan.

\section{Tema 2: Motivasi Ekstrinsik}

Berdasarkan hasil analisis data, peneliti menemukan tujuh aspek dalam motivasi ekstrinsik, yaitu fasilitas, kewajiban, ajakan, peran pasangan, keuntungan atau benefit, mengisi waktu luang, dan social pressure. Peneliti akan memaparkan ketujuh aspek, namun terdapat empat aspek sebagai temuan utama yang akan dibahas karena temuan pendukung kurang relevan untuk dijelaskan pada penelitian ini.

\section{a. Fasilitas}

Tiga dari enam responden menyatakan bahwa mendapatkan fasilitas berupa baju seragam merupakan salah satu pendorong responden untuk berpartisipasi pada tradisi Omed-omedan. Setiap tahun, peserta tradisi Omed-omedan menggunakan baju seragam berupa kaos dengan warna dan desain yang sama. Jumlah pakaian yang disediakan terkadang kurang dari jumlah anggota STT sehingga mendapatkan fasilitas berupa baju seragam merupakan salah satu kesempatan bagi remaja di Banjar Kaja, Kelurahan Sesetan, Denpasar untuk berpartisipasi pada tradisi Omedomedan.

\section{b. Kewajiban}

Salah satu responden menyebutkan bahwa mengikuti tradisi Omed-omedan merupakan sebuah kewajiban. Responden merasa khawatir jika tradisi Omed-omedan tidak dilaksanakan, karena pada jaman dahulu, tradisi Omed-omedan sempat ditiadakan kemudian muncul dua ekor babi yang berkelahi. Setelah dicari tahu, ternyata sesuhunan di Banjar Kaja, Kelurahan Sesetan menginginkan tradisi Omed-omedan dilaksanakan setiap tahun.

\section{c. Ajakan}

Dua dari enam responden menyatakan bahwa respon mendapat ajakan dari teman-teman di banjar agar mau berpartisipasi pada tradisi Omed-omedan. Ajakan tersebut mendorong kedua responden yang sempat merasa malu dan tidak siap untuk berpartisipasi pada tradisi Omed-omedan.

\section{d. Peran Pasangan}

Tiga dari enam pernyataan responden menunjukkan bahwa peran pasangan menjadi salah satu aspek yang mendorong ketiga responden untuk berpartisipasi pada tradisi Omed-omedan. Peran yang dimaksud adalah seperti pacar responden yang menjadi pasangan saat pelaksanaan tradisi Omed-omedan sehingga mampu mengurangi rasa cemas responden serta pacar responden yang mampu mengerti dan mengizinkan responden untuk berpartisipasi pada tradisi Omedomedan.

\section{e. Keuntungan atau Benefit}

Pernyataan empat responden menunjukkan bahwa mengikuti tradisi Omed-omedan memberikan keuntungan atau benefit yang dapat memberikan penguatan terhadap partisipasi pada tradisi Omedomedan. Keuntungan-keuntungan tersebut yaitu berupa kesempatan untuk melestarikan tradisi, memperluas pergaulan responden, dan mempererat hubungan antaranggota STT di Banjar Kaja, Kelurahan Sesetan, Denpasar.

\section{f. Mengisi Waktu Luang}

Pernyataan salah satu responden menunjukkan bahwa responden memiliki waktu luang untuk berpartisipasi pada tradisi Omed-omedan. Responden yang menyatakan perasaan tidak nyaman jika hanya berdiam 
diri di rumah menunjukkan bahwa responden memiliki waktu luang untuk berpartiisipasi pada tradisi Omedomedan. Responden tidak mungkin sengaja menghindari tradisi Omed-omedan karena terdapat mitos bahwa orang yang sengaja menghindar dan bepergian saat tradisi Omed-omedan berlangsung akan terjadi kesialan pada orang tersebut.

\section{g. Social Pressure}

Pernyataan tiga dari enam responden menunjukkan bahwa ketiga responden mendapatkan tekanan dari lingkungan sosial, atau yang biasa disebut social pressure. Tekanan-tekanan sosial tersebut berupa rasa sungkan untuk menolak ajakan teman-teman, suruhan dari teman-teman dan orangtua, serta paksaan dari tetua-tetua di banjar.

\section{Tema 3: Faktor Penghambat}

Selain motivasi, peneliti menemukan adanya faktor penghambat yang dapat memengaruhi motivasi partisipasi remaja putri pada tradisi Omed-omedan di Banjar Kaja, Kelurahan Sesetan, Denpasar. Faktor-faktor penghambat tersebut dikelompokkan menjadi dua, yaitu faktor penghambat internal dan eksternal.

\section{a. Faktor Penghambat Internal}

Faktor penghambat internal dibagi menjadi tiga aspek, yaitu keinginan, persepsi, dan lelah. Peneliti akan menjabarkan hasil wawancara ketiga aspek, namun hanya akan menjabarkan penjelasan satu aspek, yaitu persepsi, sebagai temuan utama yang lebih urgent untuk dijelaskan pada penelitian ini.

1. Lelah

Salah satu responden menyatakan bahwa responden sempat tidak mengikuti tradisi Omedomedan karena merasa lelah setelah menjadi panitia pada acara pembukaan Sesetan Heritage Omedomedan Festival (SHOOF)

\section{Keinginan}

Dua dari enam responden mengatakan bahwa responden sempat tidak berpartisipasi pada tradisi Omed-omedan karena tidak adanya keinginan responden untuk berpartisipasi.

\section{Persepsi}

Pernyataan empat dari enam responden menunjukkan bahwa responden memiliki persepsi yang keliru terkait tradisi Omed-omedan. Persepsi tersebut sempat membuat responden merasa belum siap, malu, dan takut untuk berpartisipasi pada tradisi Omed-omedan.

\section{b. Faktor Penghambat Eksternal}

Faktor penghambat yang dikategorikan sebagai faktor penghambat eksternal terdiri dari tujuh aspek. Peneliti akan membahas hasil wawancara setiap aspek, namun hanya tiga aspek sebagai temuan utama yang akan dibahas pada bagian pembahasan karena lebih urgent untuk dibahas pada penelitian ini.

\section{Sikap Pasangan}

Pernyataan dua dari enam responden menunjukkan bahwa responden mempertimbangkan partisipasi pada tradisi Omed-omedan karena sikap pasangan atau pacar masing-masing responden. Sikapsikap tersebut seperti cemburu, berpikiran negatif, dan tidak mengizinkan responden berpartisipasi pada tradisi Omed-omedan.

2. Ketersediaan Waktu

Dua dari enam responden mengatakan bahwa responden tidak dapat berpartisipasi pada tradisi Omed-omedan karena kesibukan lain sehingga memengaruhi ketersediaan waktu responden.

\section{Ketersediaan Fasilitas}

Salah satu responden menyatakan bahwa responden tidak mendapat surat undangan untuk menjadi peserta pada tradisi Omed-omedan. Surat yang diberikan oleh banjar hanya sampai di rumah tua responden di Banjar Kaja, Kelurahan Sesetan, Denpasar, sedangkan responden tinggal di luar Sesetan.

\section{Tidak Ada yang Mengajak}

Salah satu responden mengatakan bahwa responden tidak berpartisipasi pada tradisi Omedomedan karena tidak mendapat ajakan dari temanteman di banjar. Responden yang saat itu baru bergabung menjadi anggota STT di Banjar Kaja, Kelurahan Sesetan, Denpasar belum mengenal anggota-anggota STT lainnya. Hal ini menyebabkan responden merasa enggan untuk hadir dan berpartisipasi pada tradisi Omed-omedan. Seiring berjalannya waktu, responden yang sudah mengenal beberapa anggota STT mulai mendapat ajakan dan memutuskan untuk berpartisipasi pada tradisi Omedomedan.

\section{Tidak Mengenal Anggota STT Lain}


Hasil wawancara menunjukkan bahwa tidak mengenal anggota-anngota STT di Banjar Kaja, Kelurahan Sesetan, Denpasar membuat responden kurang nyaman untuk berbaur dalam kegiatan Omedomedan. Selain itu, responden merasa takut karena tidak mengenal pemuda-pemuda di Banjar Kaja, Kelurahan Sesetan, Denpasar yang salah satunya akan menjadi pasangan responden saat pelaksanaan tradisi Omed-omedan.

\section{Cuntaka}

Cuntaka atau sebel adalah suatu keadaan tidak suci menurut pandangan agama Hindu (Babad Bali, 2013). Salah satu faktor yang menyebabkan seseorang dalam keadaan tidak suci dalam ajaran agama Hindu adalah menstruasi. Menstruasi merupakan hal alamiah yang rutin dialami perempuan setiap bulan, sehingga menstruasi dapat menjadi faktor penghambat partisipasi remaja putri di Banjar Kaja, Kelurahan Sesetan, Denpasar jika pelaksanaan tradisi Omed-omedan bertepatan dengan masa menstruasi remaja putri tersebut.

\section{PEMBAHASAN}

\section{Tema 1: Motivasi Intrinsik}

Peneliti menemukan bahwa terdapat enam aspek motivasi intrinsik. Empat dari enam aspek merupakan temuan utama, yaitu rasa ingin tahu atau curiousity, belief, prinsip, rasa bangga atau pride, dan informasi baru.

\section{a. Rasa Ingin Tahu atau Curiousity}

Berlyne (1960) percaya bahwa rasa ingin tahu merupakan prasyarat motivasi untuk perilaku eksplorasi. Hunt (dalam Ainina, 2016) juga menyatakan bahwa rasa ingin tahu mengacu pada "motivasi yang melekat dalam pengolahan informasi" yang berarti rasa ingin tahu adalah campuran dari kognisi dan motivasi.

Tiga dari tujuh responden menyatakan bahwa responden merasa penasaran dengan tradisi Omedomedan. Dua diantaranya menyatakan bahwa responden pertama kali menonton Omed-omedan saat SD dan satu diantaranya saat SMP. Pengalaman menonton tradisi Omed-omedan menimbulkan rasa ingin tahu pada ketiga respoden. Hal ini sejalan dengan dengan pendapat Mustari (2011) yang menyatakan bahwa rasa ingin tahu merupakan sikap dan tindakan yang selalu berupaya untuk mengetahui lebih mendalam dan meluas dari apa yang dipelajarinya, dilihat dan didengar.

Pernyataan Kartono (1979) menunjukkan bahwa anak-anak SD yang pada umumnya berada pada rentang usia 6-12 tahun memiliki rasa ingin tahu yang tinggi. Selain itu, Ali (2010) juga menyebutkan salah satu karakteristik umum perkembangan remaja adalah memiliki rasa ingin tahu yang tinggi (high curiosity). Rasa ingin tahu yang tinggi pada remaja mendorong remaja untuk cenderung ingin bertualang, menjelajah segala sesuatu, dan mencoba segala sesuatu yang belum pernah dialaminya. Pernyataan tersebut sejalan dengan tiga responden yang memiliki rasa ingin tahu pada tradisi Omed-omedan saat responden SD dan SMP, sehingga ketiga responden tersebut memilih untuk berpartisipasi pada tradisi Omed-omedan.

Berlyne (1960) percaya bahwa rasa ingin tahu merupakan prasyarat motivasi untuk perilaku eksplorasi. Responden meyatakan bahwa responden ingin merasakan sendiri bagaimana prosesi Omedomedan tersebut. Hal ini menunjukkan bahwa rasa ingin tahu mendorong responden untuk bereksplorasi dengan berpartisipasi dalam tradisi Omed-omedan. Perilaku responden juga sejalan dengan pernyataan Shiau dan $\mathrm{Wu}$ (2013) yang mendefinisikan rasa ingin tahu sebagai keinginan dan jenis motivasi intrinsik untuk mengetahui, memahami, atau mengalami yang menimbulkan perilaku eksplorasi untuk mendapatkan informasi baru dan pengalaman sensorik. Rasa ingin tahu yang terpenuhi akan menimbulkan kepuasan pada individu.

\section{b. Kepercayaan atau Belief}

Secara umum, belief diartikan sebagai keyakinan atau kepercayaan individu terhadap sesuatu. Kepercayaan atau keyakinan memang dimiliki oleh semua kelompok masyarakat dan suku bangsa yang pada awalnya bersumber dari sistem kepercayaan dalam kebudayaan (Hady, 2015). Hal ini sejalan dengan pernyataan responden yang menyatakan bahwa responden memiliki kepercayaan terhadap sesuhunan di Banjar Kaja. Kelurahan Sesetan, Denpasar, Denpasar yang pada awalnya muncul karena tradisi Omed-omedan.

Hebding \& Glick (1992) mengemukakan bahwa kepercayaan merupakan gagasan yang dimiliki oleh orang atau kelompok tentang sebagian atau keseluruhan realitas dunia yang mengelilingi individu. Kepercayaan yang terdapat pada 
masyarakat tertentu dapat menjadi sebuah standar terhadap perilaku, dan sikap masyarakat agar tidak melanggar nilai dan norma yang berlaku dalam masyarakat tersebut (Hady, 2015). Hal ini sejalan dengan perilaku responden yang tetap berpartisipasi pada tradisi Omed-omedan walaupun sedang memiliki pacar yang bukan berasal dari Banjar Kaja, Kelurahan Sesetan, Denpasar, Denpasar dan pacar responden menunjukkan sikap seperti menyindir dan cemburu. Perilaku responden tersebut, berdasarkan pernyataan Hady (2015), adalah karena responden memiliki kepercayaan atau belief yang menjadi standar perilaku dan sikap responden pada tradisi Omed-omedan.

\section{c. Prinsip}

Prinsip merupakan asas atau kebenaran yang menjadi pokok dasar individu dalam berpikir, bertindak dan sebagainya (Alwi, 2007). Sebagai generasi muda di Banjar Kaja, Kelurahan Sesetan, Denpasar, responden memiliki prinsip bahwa responden akan berpartisipasi dalam tradisi Omedomedan selama responden masih memiliki kesempatan tersebut.

Prinsip yang dimiliki responden juga dapat disebut sebagai nilai yang bersifat individual. Menurut Sarwono \& Meinarno (2009), nilai dapat diartikan sebagai pedoman normatif pada diri seseorang yang memengaruhi pemilihan sejumlah alternatif dalam bertindak. Nilai dapat dilihat sebagai penyedia kerangka perseptual yang stabil dalam memengaruhi perilaku seseorang karena dibangun dan berkembang melalui pengalaman serta interaksi dengan lingkungan jauh sebelum individu menginjak dewasa (Sarwono \& Meinarno, 2009). Hal ini sejalan dengan perilaku responden yang menjadikan prinsip responden untuk berpartisipasi pada tradisi Omedomedan. Sarwono \& Meinarno (2009) juga menyimpulkan bahwa nilai dapat dilihat sebagai refleksi dari keyakinan yang mengarahkan tindakan, pertimbangan, dan pengambilan keputusan sebagai akhir dari proses yang terjadi dalam individu.

\section{d. Rasa Bangga atau Pride}

Dua dari tujuh responden menyatakan bahwa responden merasa bangga dengan mengikuti tradisi Omed-omedan. Hal ini sejalan dengan hasil penelitian Mahardika (2013) yang menyatakan bahwa 64,9\% warga Banjar Kaja, Kelurahan Sesetan, Denpasar setuju bahwa tradisi ini menimbulkan kebanggaan. Rasa bangga yang dirasakan kedua responden muncul setelah responden berpartisipasi dalam tradisi Omed-omedan. Pernyataan responden tersebut sejalan dengan pendapat Lewis (2011) dan Tangney, dkk., (2007) yang menyatakan bahwa rasa bangga muncul sebagai hasil evaluasi individu yang telah memenuhi standar, tujuan, dan aturan dalam tatanan sosial. Penelitian yang dilakukan oleh Mariantika (2016) tentang pengalaman emosi yang mendasari tindakan individu dalam kehidupan seharihari menunjukkan bahwa pada individu kategori usia remaja, tidak ditemukan tema emosi positif yang muncul sebelum bertindak sesuai standar sosial, baik yang bekaitan dengan pencapaian tujuan bertahan hidup maupun pencapaian tujuan identitas. Hal ini menunjukkan bahwa hasil penelitian tersebut sejalan dengan pernyataan responden yang merasakan emosi positif, yaitu rasa bangga, setelah berpartisipasi dalam tradisi Omed-omedan.

Rasa bangga juga dapat muncul ketika individu berhasil menggolongkan dirinya dalam suatu kelompok, atau disebut juga identitas sosial. Identitas sosial (social identity) merujuk pada cara individu mendefinisikan diri dalam kaitannya dengan keanggotaan individu dalam sebuah kelompok (Deaux dalam King, 2010). Menurut Brewer \& Gardiner (dalam Sarwono \& Meinarno, 2009), terdapat tiga bentuk diri yang menjadi dasar bagi seseorang dalam mendefinisikan dirinya yaitu individual self, relational self, dan collctive self.

Pernyataan responden yang merasa bangga berpartisipasi pada tradisi Omed-omedan menunjukkan bahwa responden sedang mendefinisikan dirinya dalam bentuk collective self, yaitu responden mendefinisikan diri berdasarkan keanggotaan kelompok sosial responden. Keanggotaan kelompok sosial yang dimaksud adalah keanggotaan sebagai remaja di Banjar Kaja, Kelurahan Sesetan, Denpasar yang melaksanakan tradisi Omed-omedan dimana tradisi ini hanya dilaksanakan di Banjar Kaja, Kelurahan Sesetan, Denpasar.

Menurut Sarwono \& Meinarno (2009), tingkah laku seseorang tidak hanya dipengaruhi oleh pengetahuan tentang siapa dirinya namun juga dipengaruhi oleh penilaian atau evaluasi terhadap dirinya. Jika individu menilai diri secara positif maka individu menjadi percaya diri dalam mengerjakan suatu hal. Sebaliknya, orang yang menilai dirinya secara negatif akan menjadi tidak percaya diri dalam melakukan sesuatu (Sarwono \& Meinarno, 2009). 
Penilaian secara positif atau negatif terhadap diri ini disebut harga diri (self esteem) (Deaux, Dane, \& Wrightsman dalam Sarwono \& Meinarno, 2009). Dua responden yang merasa bangga mengikuti tradisi Omed-omedan berarti menilai dirinya yang tergabung sebagai remaja di Banjar Kaja, Kelurahan Sesetan, Denpasar sebagai hal yang positif.

Rasa bangga menunjukkan bahwa individu memiliki self esteem yang positif. Maslow (dalam Robins \& Judge, 1996) membuat hipotesis bahwa dalam setiap diri manusia terdapat hierarki dari lima kebutuhan, yaitu kebutuhan fisiologis (physiological needs), kebutuhan akan rasa aman (safety needs), kebutuhan akan cinta dan kepemilikan (love and belongingness needs), kebutuhan akan penghargaan (esteem needs), dan kebutuhan akan aktualisasi diri (self-actualization needs).

Jika dilihat berdasarkan pemaparan teori motivasi menurut Maslow, remaja putri di Banjar Kaja, Kelurahan Sesetan, Denpasar berpartisipasi pada tradisi Omed-omedan untuk mencapai kebutuhan akan penghargaan diri (esteem needs). Penghargaan diri yang positif tersebut kemudian akan memunculkan rasa bangga. Hal ini sejalan dengan pernyataan dua responden bahwa menjadi sebuah kebanggaan bagi responden jika dapat berpartisipasi pada tradisi Omed-omedan.

\section{e. Informasi Baru}

Engel, Blackwell, dan Miniard (1994) menjelaskan bahwa proses pengambilan keputusan seseorang dipengaruhi oleh faktor lingkungan, faktor perbedaan individu dan proses psikologi. Faktor psikologi yang dimaksud terdiri dari persepsi, sikap, motif, kognitif, dan pengetahuan. Pengetahuan merupakan hasil dari tahu, dan hal ini terjadi setelah seseorang melakukan penginderaan terhadap suatu objek tertentu (Ginting, 2008). Pengetahuan dapat berasal dari informasi-informasi baru yang diperoleh individu. Salah satu responden mendapat banyak informasi baru terkait tradisi Omed-omedan dari tetua-tetua di banjar yang hadir saat rapat STT, sedangkan responden lainnya mendapat informasi baru terkait tradisi Omed-omedan dari pacar responden yang menjadi pengurus STT di Banjar Kaja, Kelurahan Sesetan, Denpasar. Hal ini menunjukkan bahwa kedua responden mendapatkan informasi baru dari orang-orang disekitar responden. Informasi-informasi baru tersebut semakin memperkaya pengetahuan responden terkait tradisi Omed-omedan.

Salah satu responden pada awalnya merasa malu untuk mengikuti tradisi Omed-omedan. Setelah mendapat informasi baru terkait tradisi Omedomedan dari pacar responden, responden merasa tertantang untuk berpartisipasi pada tradisi Omedomedan. Hal ini didukung oleh pernyataan Ali (2010) bahwa salah satu karakteristik umum perkembangan remaja adalah memiliki rasa ingin tahu yang tinggi (high curiousity) sehingga remaja cenderung ingin bertualang, menjelajah segala sesuatu, dan mencoba segala sesuatu yang belum pernah dialaminya. Responden yang belum pernah berpartisipasi pada tradisi Omed-omedan menjadi tertantang untuk mencoba tradisi Omed-omedan yang merupakan pengalaman baru bagi responden.

Selain itu, perilaku responden yang merasa tertantang untuk berpartisipasi pada tradisi Omedomedan menunjukkan bahwa informasi-informasi baru yang memperkaya pengetahuan responden terkait tradisi Omed-omedan dapat memengaruhi pengambilan keputusan individu, dari yang awalnya merasa enggan berpartisipasi menjadi tertantang untuk berpartisipasi. Pernyataan tersebut berbeda dengan pendapat Green (1980) yang menyatakan bahwa peningkatan pengetahuan tidak selalu menyebabkan perubahan perilaku, tetapi pengetahuan sangat penting diberikan sebelum individu melakukan suatu tindakan.

\section{Tema 2: Motivasi Ekstrinsik}

Peneliti menemukan tujuh aspek motivasi ekstrinsik, dimana pada penelitian ini peneliti menetapkan empat aspek yang menjadi temuan utama. Temuan-temuan utama tersebut antara lain kewajiban, peran pasangan, keuntungan atau benefit, dan social pressure.

\section{a. Kewajiban}

Kamus Besar Bahasa Indonesia menyebutkan bahwa kewajiban merupakan sesuatu yang harus dilaksanakan (Alwi, 2007). Rasa wajib yang dinyatakan responden muncul akibat kepatuhan terhadap seseorang atau sesuatu yang dipercaya memiliki kekuasaan atau power. Perilaku tersebut, dalam psikologi sosial, disebut sebagai obedience atau kepatuhan (Sarwono \& Meinarno, 2009). Obedience merupakan salah satu jenis dari pengaruh sosial, dimana seseorang manaati dan mematuhi permintaan orang lain untuk melakukan tingkah laku 
tertentu karena adanya unsur power (Baron, Branscombe, \& Byrne dalam Sarwono \& Meinarno, 2009). Dalam konteks ini, power yang dimaksud dimiliki oleh sesuhunan di Pura Bale Banjar yang diyakini memiliki kuasa atas keberlangsungan kesejahteraan manusia.

Kesadaran responden terhadap kewajiban mengikuti tradisi Omed-omedan juga dapat dijelaskan dengan teori identitas sosial. Identitas sosial (social identity) merujuk pada cara individu mendefinisikan diri dalam kaitannya dengan keanggotaan individu dalam sebuah kelompok (Deaux, 2001 dalam King, 2010). Hal ini sejalan dengan responden yang menyadari kewajibannya dalam keanggotaan responden pada sebuah kelompok, yaitu sebagai remaja putri di Banjar Kaja, kelurahan Sesetan, Denpasar yang memiliki tugas untuk menjalankan dan melestarikan tradisi Omedomedan.

\section{b. Peran Pasangan}

Taylor, dkk. (2009) menyebutkan bahwa dukungan sosial dapat bersumber dari pasangan atau partner, anggota keluarga, teman, kontak sosial dan masyarakat, teman sekelompok, komunitas religi dan teman kerja. Dukungan sosial (social support) adalah informasi dan umpan balik dari orang lain yang menunjukkan bahwa seseorang dicintai dan diperhatikan, dihargai, dihormati, dan dilibatkan dalam jaringan komunikasi dan kewajiban yang timbal balik (King, 2010). Menurut Sarafino (dalam Kumalasari \& Lathifa, 2012) dukungan sosial terdiri dari empat dimensi, yaitu: (1) dukungan emosional seperti memberikan perhatian dan afeksi; (2) dukungan penghargaan berupa pernyataan setuju dan penilaian positif terhadap ide-ide, perasaan dan performa orang lain; (3) dukungan instrumental seperi bantuan finansial atau bantuan dalam mengerjakan tugas-tugas tertentu; (4) dukungan informasi berupa saran, pengarahan dan umpan balik tentang bagaimana cara memecahkan persoalan.

Dua responden sedang berpacaran dengan lakilaki dari luar Banjar Kaja, Kelurahan Sesetan, Denpasar saat penggalian data dilakukan. Pacar responden memberikan izin dan mengerti kewajiban responden untuk berpartisipasi pada tradisi Omedomedan. Berdasarkan teori dukungan sosial menurut Sarafino (dalam Kumalasari \& Latifha, 2012), sikap pasangan kedua responden tersebut merupakan bentuk dukungan penghargaan. Hal ini menyebabkan responden merasa nyaman untuk berpartisipasi pada tradisi Omed-omedan dan pacar responden juga tidak terbebani dengan partisipasi responden.

\section{c. Keuntungan atau Benefit}

Teori penguatan menunjukkan bagaimana konsekuensi tingkah laku dimasa lampau akan memengaruhi tindakan dimasa depan dalam proses belajar. Menurut Robbins \& Coulter (2007), segala sesuatu yang mengendalikan perilaku disebut penguat dan konsekuensi atau hasil perilaku dapat meningkatkan kemungkinan perilaku tersebut akan diulang. Hal ini berarti perilaku yang mendapatkan konsekuensi atau hasil yang positif dan menyenangkan akan diulangi kembali dan ketika suatu perilaku menghasilkan konsekuensi yang negatif atau tidak menyenangkan, maka individu cenderung untuk tidak mengulangi perilaku tersebut.

Pernyataan beberapa responden menunjukkan bahwa mengikuti tradisi Omed-omedan dapat memperluas pergaulan responden. Menurut Pearson (dalam Sarwono \& Meinarno, 2009), manusia adalah makhluk sosial sehingga manusia selalu menjalin hubungan dengan orang lain. Menurut Sarwono \& Meinarno (2009), faktor-faktor yang memengaruhi suatu ketertarikan interpersonal (interpersonal attraction) yaitu faktor internal, eksternal dan interaksi.

1. Faktor internal meliputi dua hal, yaitu kebutuhan untuk berinteraksi (need for affiliation) dan pengaruh perasaan. Menurut McClelland (dalam Sarwono \& Meinarno, 2009), kebutuhan berinteraksi adalah suatu keadaan dimana seseorang berusaha untuk mempertahankan suatu hubungan, bergabung dalam kelompok, berpartisipasi dalam kegiatan, menikmati aktivitas bersama keluarga atau teman, menunjukkan perilaku saling bekerja sama, saling mendukung, dan konformitas.

2. Faktor eksternal yang terdiri dari dua hal, yaitu kedekatan (proximity) dan daya tarik fisik. Baron \& Byrne (dalam Sarwono \& Meinarno, 2009) menjelaskan bahwa semakin dekat jarak geografis diantara mereka, semakin besar kemungkinan kedua orang tersebut untuk sering bertemu hingga akhirnya timbul ketertarikan diantara mereka. 
3. Faktor interaksi yang terdiri dari persamaanperbedaan (similarity-dissimilarity) dan reciprocal liking.

Berdasarkan pemaparan tersebut, pernyataan responden yang menunjukkan bahwa berpartisipasi dalam tradisi Omed-omedan dapat memperluas pergaulan responden dapat dijelaskan dengan teori McClelland (dalam Sarwono \& Meinarno, 2009) dimana responden memiliki faktor-faktor ketertarikan interpersonal yang bersifat intrinsik berupa kebutuhan untuk berinteraksi dan faktor ekstrinsik berupa kedekatan atau proximity.

Dua responden juga mengatakan bahwa mengikuti tradisi Omed-omedan dapat mempererat hubungan persaudaraan antaranggota STT. Hal ini didukung oleh pernyataan Muhammad (2001) bahwa salah satu arti penting partisipasi adalah dapat meningkatkan sense of group cohesiveness atau perasaan menjadi satu kesatuan, dan selanjutnya akan meningkatkan kerjasama diantara anggota kelompok.

\section{d. Social Pressure}

Dua responden menyatakan bahwa responden mendapat ajakan untuk berpartisipasi pada tradisi Omed-omedan dari teman-teman STT di Banjar Kaja, Kelurahan Sesetan, Denpasar. Salah satu responden yang baru bergabung menjadi anggota STT saat kelas 1 SMA mendapat anjuran dan ajakan untuk berpartisipasi dalam tradisi Omed-omedan. Meskipun sebenarnya responden merasa tidak ingin dan takut untuk berpartisipasi, akhirnya responden memutuskan untuk berpartisipasi dalam tradisi Omed-omedan.

Perubahan perilaku kedua responden merupakan salah satu dampak dari pengaruh sosial, yaitu konformitas. Cialdini \& Goldstein (dalam Taylor, dkk., 2009) mendefinisikan konformitas sebagai tendensi untuk mengubah keyakinan atau perilaku seseorang agar sesuai dengan perilaku orang lain. Konformitas terjadi apabila individu mengadopsi sikap atau perilaku orang lain karena merasa didesak oleh orang lain, baik desakan nyata atau bayangan saja (Santrock, 2007). Berbeda dengan pendapat Taylor, dkk., (2009) yang menyatakan bahwa dalam budaya kolektivis, konformitas dianggap bukan sebagai respons terhadap desakan sosial, tetapi sebagai cara untuk menjalin hubungan dengan orang lain dan untuk memenuhi kewajiban moral.
Selama masa remaja, individu menghabiskan lebih banyak waktu bersama teman sebaya dibandingkan saat masih kanak-kanak (King, 2010). Selain teman sebaya, kelompok atau organisasi juga penting pada masa remaja. Hal ini sejalan dengan pendapat Brown; Mahoney, Larson \& Eccles; Roth \& Brooks-Gunn (dalam Santrock, 2007) yang menyatakan bahwa organisasi pemuda dapat memiliki pengaruh yang penting bagi perkembangan. Para remaja yang bergabung dengan kelompok semacam itu cenderung akan berpartisipasi dalam aktivitas-aktivitas komunitas orang dewasa dan memiliki harga diri yang lebih tinggi, lebih terdidik, dan berasal dari keluarga dengan penghasilan yang lebih tinggi dibandingkan kawan-kawannya yang tidak berpartisipasi dalam organisasi remaja (Erickson dalam Santrock, 2007).

Responden lainnya menyatakan bahwa responden mendapat suruhan dari orangtua responden untuk berpartisipasi dalam tradisi Omed-omedan. Perilaku orangtua responden sejalan dengan pernyataan Berry, Poortinga, Segall \& Dasen (dalam Taylor, dkk., 2009) bahwa orangtua sangat memerhatikan kepatuhan, perilaku yang tepat, dan penghormatan terhadap tradisi kelompok.

Selain mendapat suruhan dari teman-teman, salah satu responden juga menyatakan bahwa responden dipaksa oleh tetua-tetua di banjar untuk berpartisipasi dalam tradisi Omed-omedan. Responden mengaku awalnya dipaksa, namun setelah mengikuti tradisi Omed-omedan, keputusan untuk mengikuti tradisi Omed-omedan tidak lagi karena paksaan tersebut.

Pernyataan kedua responden tersebut menunjukkan bahwa responden mendapat tekanan sosial dari orangtua dan tetua-tetua di Banjar Kaja, Kelurahan Sesetan, Denpasar. Pada umumnya individu cenderung mengikuti permintaan atau perintah orang lain yang dianggap memiliki kekuatan atau power. Perilaku-perilaku ini, dalam psikologi sosial, disebut sebagai obedience atau kepatuhan (Sarwono \& Meinarno, 2009). Obedience merupakan salah satu jenis dari pengaruh sosial, dimana seseorang manaati dan mematuhi permintaan orang lain untuk melakukan tingkah laku tertentu karena adanya unsur power (Baron, Branscombe, \& Byrne dalam Sarwono \& Meinarno, 2009).

\section{Tema 3: Faktor Penghambat}


Selain motivasi, peneliti menemukan adanya faktor penghambat yang dapat memengaruhi motivasi partisipasi remaja putri di Banjar Kaja, Kelurahan Sesetan, Denpasar pada tradisi Omed-omedan. Faktor-faktor penghambat tersebut dikelompokkan menjadi dua, yaitu faktor penghambat internal dan eksternal.

\section{a. Faktor Penghambat Internal}

Berdasarkan hasil pengolahan data, faktor penghambat internal terdiri dari tiga aspek. Satu diantaranya merupakan temuan utama, yaitu persepsi.

\section{Persepsi}

G. R. Terry (dalam Syamsi, 2000) menyatakan bahwa terdapat empat dasar dari pengambilan keputusan yang berlaku, yaitu intuisi, pengalaman, fakta, wewenang dan rasional. Keputusan yang berdasarkan pengalaman sangat bermanfaat bagi pengetahuan praktis. Pengalaman dan kemampuan untuk memperkirakan apa yang menjadi latar belakang masalah dan bagaimana arah penyelesaiannya sangat membantu dalam memudahkan pemecahan masalah. Faktor pengalaman tersebut sejalan dengan pengalaman dua responden yang pernah melihat peserta Omed-omedan hingga berciuman. Pengalaman tersebut menimbulkan rasa tidak siap dan malu pada responden sehingga responden sempat memutuskan untuk tidak berpartisipasi pada tradisi Omed-omedan.

Berbeda dengan pendapat Engel, Blackwell, dan Miniard (1994) yang menjelaskan bahwa proses pengambilan keputusan seseorang dipengaruhi oleh tiga faktor, antara lain:

1. Faktor lingkungan, terdiri dari faktor lingkungan sosial dan lingkungan keluarga

2. Faktor perbedaan individu, seperti status sosial, kebiasaan, simbol pergaulan, dan tututan

3. Faktor psikologi, terdiri dari persepsi, sikap, motif, kognitif, dan pengetahuan

Faktor persepsi tersebut berasal dari pengalaman individu. Hal ini didukung oleh pendapat Krech \& Crutchfield (1962) mengatakan bahwa persepsi dipengaruhi oleh:

1. Frame of reference, yaitu kerangka pengetahuan yang dimiliki dan diperoleh dari pendidikan, bacaan, penelitian, atau cara lain.

2. Frame of experience, yaitu pengalaman yang telah dialami individu yang tidak terlepas dari dari keadaan lingkungan.

Pemaparan tersebut menyimpulkan bahwa menurut G. R. Terry (dalam Syamsi, 2000) pengambilan keputusan didasarkan oleh pengalaman, sedangkan menurut Engel, Blackwell, dan Miniard (1994) pengambilan keputusan didasarkan oleh salah satu faktor, yaitu persepsi. Persepsi tersebut berasal dari pengalaman individu, yang didukung oleh teori Krech \& Crutchfield (1962).

\section{b. Faktor Penghambat Eksternal}

Faktor penghambat yang dikategorikan sebagai faktor penghambat eksternal terdiri dari enam aspek. Dua dari enam aspek merupakan temuan utama, yaitu sikap pasangan dan cuntaka.

\section{Sikap Pasangan}

Pernyataan tiga responden menunjukkan bahwa terdapat beberapa sikap negatif pasangan responden seperti cemburu, menyindir, berpikiran negatif, dan tidak memberi ijin pada responden untuk berpartisipasi pada tradisi Omed-omedan. Sikap negatif yang muncul pada pacar ketiga responden didukung oleh pernyataan Arifin (dalam Hakim, 2002) bahwa pacaran bagi remaja dapat memberikan dampak positif dan negatif pada empat aspek, tergantung bagaimana hubungan pacaran tersebut dijalani. Aspek-aspek tersebut antara lain:

a. Prestasi sekolah, berdampak positif apabila remaja saling memotivasi dan berdampak positif apabila remaja melakukan hal-hal seperti bolos untuk berpacaran

b. Pergaulan sosial dapat menjadi lebih luas apabila melibatkan interaksi dengan orang lain selain pacar dan menjadi menyempit apabila interaksi hanya sebatas dengan pacar

c. Aktivitas pacaran yang bisa jadi produktif atau justru mengarah pada perilaku seks bebas

d. Hubungan emosional yang dapat menimbulkan perasaan aman, nyaman, dan terlindungi atau menimbulkan perasaan stress 
Pernyataan Arifin (dalam Hakim, 2002) terkait dampak negatif pada pergaulan sosial sejalan dengan sikap dua dari tiga responden tersebut yang memutuskan untuk tidak berpartisipasi pada tradisi Omed-omedan karena sikap negatif pacar responden. Tidak berpartisipasinya responden dapat mengarah pada terbatasnya pergaulan sosial responden, khususnya pergaulan responden dengan remajaremaja lain di Banjar Kaja, Kelurahan Sesetan, Denpasar.

Berdasarkan hasil wawancara, tiga responden menyatakan bahwa pacar responden ada yang cemburu, menyindir, tidak sepenuhnya mengizinkan, dan responden merasa takut jika pacar responden akan berpikiran negatif saat responden berpartisipasi pada tradisi Omedomedan. Responden lainnya juga sempat bertanya kepada teman-teman responden yang perempuan dan menyatakan bahwa beberapa teman responden tidak mengikuti tradisi Omedomedan karena tidak diijinkan oleh pacar.

Sikap pasangan ketiga responden dan teman-teman responden merujuk pada sikap cemburu. Menurut Taylor, dkk. (2009), kecemburuan adalah reaksi terhadap ancaman yang dianggap akan mengganggu kelangsungan atau kualitas hubungan yang berharga. Ada beberapa faktor yang menimbulkan kecemburuan, yaitu ketergantungan pada hubungan, kepedulian pada hubungan, dan ketersediaan alternatif (White \& Mullen dalam Taylor, dkk., 2009), juga ada bukti hubungan cemburu dengan rasa aman (Taylor, dkk., 2009). Pacar responden kemungkinan memiliki persepsi bahwa responden akan dipeluk bahkan dicium oleh laki-laki lain sehingga pacar responden bersikap cemburu.

\section{Cuntaka}

Cuntaka atau sebel adalah suatu keadaan tidak suci menurut pandangan agama Hindu (Babad Bali, 2013). Utamanya, cuntaka disebabkan karena kematian. Cuntaka juga dapat disebabkan karena menstruasi, bersalin, keguguran, sakit (kelainan), perkawinan, incest, salah timpal atau bersetubuh dengan binatang, hamil tanpa beakaon (upacara pendahuluan selaku upacara penyucian), mitra ngalang (hubungan seks diluar perkawinan), lahir dari kehamilan tanpa upacara, dan melakukan sad atatayi (enam jenis pembunuhan).

Diantara beberapa hal yang menyebabkan cuntaka, menstruasi merupakan salah satu faktor yang hanya dapat dialami perempuan. Menstruasi merupakan hal alamiah yang rutin dialami perempuan setiap bulan, sehingga menstruasi dapat menjadi faktor penghambat partisipasi remaja putri di Banjar Kaja, Kelurahan Sesetan, Denpasar jika pelaksanaan tradisi Omed-omedan bertepatan dengan masa menstruasi remaja putri tersebut.

\section{KESIMPULAN DAN SARAN}

\section{Kesimpulan}

Secara keseluruhan, remaja putri di Banjar Kaja, Kelurahan Sesetan, Denpasar memiliki motivasi partisipasi yang bersifat intrinsik dan ekstrinsik. Motivasi intrinsik terdiri dari enam aspek, yaitu rasa ingin tahu atau curiosity, kesenangan, keyakinan atau belief, prinsip, rasa bangga atau pride, dan informasi baru. Motivasi ekstrinsik terdiri dari tujuh aspek yaitu fasilitas, kewajiban, ajakan, peran pasangan, keuntungan atau benefit, mengisi waktu luang, dan social pressure.

Selain motivasi, peneliti juga menemukan adanya faktor-faktor yang dapat menghambat motivasi partisipasi remaja putri di Banjar Kaja, Kelurahan Sesetan, Denpasar pada tradisi Omed-omedan. Faktor penghambat yang bersifat internal terdiri dari aspek keinginan, persepsi, dan lelah sedangkan faktor penghambat yang bersifat eksternal terdiri dari aspek sikap pasangan, ketersediaan waktu, ketersediaan fasilitas, tidak ada yang mengajak, tidak mengenal anggota STT lain dan cuntaka.

Berdasarkan hasil analisis data, beberapa responden menunjukkan respon yang mengarah pada koding-koding yang sama, yang kemudian mengarah pada beberapa aspek yang dinyatakan oleh lebih dari satu responden. Peneliti kemudian menyimpulkan beberapa aspek yang menonjol pada motivasi intrinsik, motivasi ekstrinsik, dan faktor penghambat internal dan eksternal berdasarkan frekuensi respon dari keenam responden.

Peneliti menyimpulkan tidak ada aspek motivasi intrinsik yang paling menonjol karena rata-rata setiap aspek disebutkan oleh dua responden. Aspek motivasi ekstrinsik yang paling menonjol adalah keuntungan atau benefit yang dinyatakan oleh empat responden. Fasilitas yang dimaksud adalah berupa pemberian seragam dan adanya keuntungan atau benefit yang diperoleh dengan berpartisipasi dalam tradisi Omed-omedan adalah keuntungan berupa melestarikan tradisi, memperluas pergaulan, serta mempererat hubungan 
antaranggota STT di Banjar Kaja, Kelurahan Sesetan, Denpasar.

Faktor penghambat internal yang paling menonjol adalah faktor persepsi yang dinyatakan oleh empat responden. Persepsi keliru yang dimiliki keempat responden mengakibatkan munculnya rasa tidak siap, malu dan takut jika berpartisipasi dalam tradisi Omed-omedan. Faktor penghambat eksternal yang paling menonjol adalah faktor sikap pasangan yang dinyatakan oleh tiga responden. Sikap pasangan masing-masing responden dapat menjadi faktor penghambat karena pacar responden bersikap cemburu, menyindir, negative thinking dan tidak mengizinkan responden untuk berpartisipasi.

\section{Saran}

Saran bagi remaja di Banjar Kaja, Kelurahan Sesetan, Denpasar adalah: (1) bagi remaja putri, agar lebih mempelajari tradisi Omed-omedan melalui bertanya dengan teman sebaya yang dianggap lebih mengerti tentang tradisi Omed-omedan, bertanya dengan orangtua atau tetua di Banjar Kaja, Kelurahan Sesetan, Denpasar; (2) bagi remaja putra, agar menjalankan tradisi Omed-omedan sesuai dengan aturan yang berlaku terkait pelaksanaan tradisi Omed-omedan; (3) menjadi agen sosialisasi bagi anggota STT yang baru bergabung dan anakanak di Banjar Kaja, Kelurahan Sesetan, Denpasar agar tidak terjadi kesalahan persepsi.

Saran bagi masyarakat di Banjar Kaja, Kelurahan Sesetan, Denpasar, khususnya orangtua dan tetua-tetua agar terus mensosialisasikan makna tradisi beserta perubahan aturan-aturan dalam melaksanakan tradisi Omed-omedan kepada generasi muda di Banjar Kaja, Kelurahan Sesetan, Denpasar sehingga meminimalisir kesalahan persepsi terkait tradisi Omed-omedan dan memengaruhi motivasi partisipasi generasi muda di Banjar Kaja, Kelurahan Sesetan, Denpasar pada tradisi Omed-omedan.

Saran bagi media massa adalah agar memberikan informasi yang lebih objektif dan meminimalisir pembuatan dan penyebaran artikel atau berita terkait tradisi Omedomedan yang bersifat subjektif. Selain itu media massa diharapkan turut menjadi media sosialisasi bagi masyarakat luas terkait adanya perubahan dan ketegasan aturan pada pelaksanaan tradisi Omed-omedan yang hanya memperbolehkan peserta sebatas berpelukan.

Saran bagi penelitian selanjutnya adalah diharapkan peneliti selanjutnya dapat lebih memperkaya subjek penelitian, seperti remaja putra, atau meneliti aspek psikologis lainnya terkait tradisi Omed-omedan.

\section{DAFTAR PUSTAKA}

Ach. Wazir Ws., et al., ed. 1999. Panduan penguatan menejemen lembaga swadaya masyarakat. Jakarta: Sekretariat Bina
Desa dengan dukungan AusAID melalui Indonesia HIV/AIDS and STD Prevention and Care Project.

Ainina, V. Q. (2016). Hubungan antara rasa ingin tahu biologi dengan kemampuan literasi sains. Naskah Tidak Dipublikasikan. Fakultas Matematika dan Ilmu Pengetahuan Alam Universitas Negeri Semarang, Semarang.

Ali, M. (2010). Panduan Hidup Sehat. Jakarta: Kompas Media Nusantara.

Alwi, Hasan. (2007). Kamus besar bahasa Indonesia. Jakarta: Balai Pustaka.

Anonim. Retrieved Januari 12, 2017 from Kompasiana: http://www.kompasiana.com/www.kompasiana.comusman/ budaya-nasional-masa-kini_5535b26c6ea8340a24da42fc.

Anonim. Retrieved Maret 02, 2017 from Babad Bali: http://www.babadbali.com/canangsari/hkt-caturcuntaka.htm.

Berlyne, D. E. (1960). Conflict, arousal, and curiousity. New York: McGraw Hill.

Cahyadinata, I. P. A. A. (2013). Perspektif sosio-budaya dan religius terhadap tradisi Med-Medan di Banjar Kaja, Desa Pakraman Sesetan, Kota Denpasar, Bali. Naskah Tidak Dipublikasikan. Jurusan Pendidikan Pancasila dan Kewarganegaraan Fakultas Ilmu Sosial Universitas Pendidikan Ganesha. Singaraja.

Dwijayanthi, I. A. M. G. (2016). Motivasi partisipasi kembang desa di Banjar Kaja, Kelurahan Sesetan dalam tradisi Omedomedan. Naskah Tidak Dipublikasikan. Program Studi Psikologi Fakultas Kedokteran Universitas Udayana. Denpasar.

Engel, J.F., Blackwell, R.D., Miniard. P.W. (1994). Perilaku konsumen. Jakarta: Bina Rupa.

Erdianto, K. (2017, Maret 09). Retrieved Maret, 17, 2017, from Kompas:

http://nasional.kompas.com/read/2017/03/09/08481931/kau m.perempuan.di.antara.budaya.patriarki.dan.diskriminasi.re gulasi

Ginting, Perana. (2008). Persepsi remaja terhadap perilaku seksual pranikah. Retrieved April 03, 2017 at http : //www.indoskripsi.com.

Green, Lawrence. (1980). Health education planning, a diagnostic approach. California: Mayfield Publishing.

Hady, Sholihul. (2015). Tradisi ngarot sebagai kontrol pergaulan remaja di Desa Lelea, Indramayu. Naskah Tidak Dipublikasikan. Fakultas Ilmu Tarbiyah dan Keguruan Universitas Islam Negeri Syarif Hidayatullah. Jakarta.

Hakim. (2002). Prosedur penelitian. Jakarta: Rineka Cipta.

Hebding, E.D. \& Glick, L. (1992). Introduction to sociology. New York: Mc Graw Hill.

Himpsi. (2010). Kode etik psikologi Indonesia. Jakarta: Pengurus Pusat.

Juditha, C. (2015). Gender dan seksualitas dalam konstruksi media massa. Makassar: Balai Besar Pengkajian dan Pengembangan Komunikasi dan Informatika (BBPPKI) Makassar Kementerian Komunikasi dan Informatika RI Kartono, Kartini. (1979). Psikologi anak. Bandung: Alumni.

King, A. Laura. (2010). Psikologi umum. Jakarta: Salemba Humanika. 
Krech, D. \& Crutchfield, R. (1962). Individual in society. Tokyo: McGraw-Hill Kogakusha, Ltd.

Kumalasari, F \& Latifah N. A. (2012). Hubungan antara dukungan sosial dengan penyesuaian diri remaja di panti asuhan. Jurnal Psikologi Pitutur, 1(1).

Lepper, M.R.., Iyengar, S.S \& Corpus, J.H. (2005). Intrinsic and extrinsic motivational orientations in the classroom: age differences and academic correlates. Journal of education psychology, 97(2), 184 - 196. American Psychological Association. Doi:10.1037/0022-0663.97.2.184.

Lewis, M. (2011). The self conscious emotion. encyclopedia on early childhood development. USA: Institue for the Study of Child Development, UMDNJ-Robert Wood Johnson Medical School, Child Health Institue.

Mahardika, I Wayan D. R. (2013). Festival heritage Omed-omedan sebagai daya tarik wisata di Sesetan, Denpasar. JUMPA, $1(2)$.

Mariantika, V. D. H. (2016). Pengalaman emosi yang mendasari tindakan individu dalam kehidupan sehari-hari. Naskah Tidak Dipublikasikan. Fakultas Psikologi Universitas Sanata Dharma. Yogyakarta.

Moleong, J.L. (2014). Metodologi penelitian kualitatif. Bandung: PT. Remaja Rosdakarya.

Muhammad, Arni. (2001). Komunikasi organisasi. Bandung: Bumi Aksara.

Munggah, I Made. (2008). Med-medan tradisi unik dari Sesetan. Denpasar: Pustaka Bali Post.

Mustari, Mohamad. (2011). Nilai karakter refleksi untuk pendidikan karakter. Yogyakarta: Laksbang Pressindo.

Paduarsana. (2012, Agustus 1). Retieved Januari 3, 2017, from Paduarsana: https://paduarsana.com/2012/08/01/omedomedantradisi-vs-porno-aksi/

Robbins, S.P \& Judge, T. A. (1996). Organizational behaviour, seventh edition. New Jersey: Prentice Hall Inc.

Robbins, Stephen P., \& Coulter, Mary. (2007). Manajemen. indeks, Jakarta.

Roucek, S.J \& Warren, L.R. (1984). Pengantar sosiologi. Jakarta: Bina Aksara.

Santrock, J.W. (2007). Psikologi perkembangan edisi 11 jilid 1. Jakarta: Erlangga

Sarwono, S. W. \& Meinarno, E. A. (2009). Psikologi sosial. Jakarta: Salemba Humanika.

Shiau WL \& HC Wu. (2013). Using curiosity and group-buying navigation to explore the influence of perceived hedonic value, attitude, and groupbuying behavioral intention. Jsw. 8(9).

Strauss, L. Anselm \& Corbin, Juliet. (1990). Basics of qualitative research: grounded theory procedures and techniques. Newbury Park: Sage Publications.

Sugiyono. (2013). Metode penelitian pendidikan (pendekatan kuantitatif, kualitatif, dan R\&D). Bandung: Alfabeta.

Sugiyono. (2014). Metode penelitian kuantitatif, kualitatif, dan kombinasi (mixed methods). Bandung: Alfabeta.

Syamsi, Ibnu. (2000). Pengambilan keputusan dan sistem informasi. Jakarta: Bumi Aksara.

Tangney, J. P., Stuewig, J., Mashek. (2007). Moral emotions and moral behavior. Annu Review Psychology, 58.
Taylor, Shelley E. dkk. (2009). Psikologi sosial edisi kedua belas. Jakarta: Kencana.

Uno, H.B. (2010). Perencanaan pembelajaran. Jakarta: Bumi Aksara.

Van Peursen, C. A. (1988). Strategi Kebudayaan. Yogyakarta: Kanisisus.

Widodo, W. S. (2016, Desember 01). Detik Travel. Retrieved Januari 1, 2017, from https://travel.detik.com/read/2016/12/01 /185522/3360259/1519/omed-omedan-tradisi-ciuman-yangunik-di-bali. 